\title{
膝複合勒帯損傷例に打ける後十字勒帯治療法の検討
}

深 尾 悠* 山 本 惠太郎* 矢 野 浩 明* 河 原 勝 博*
石 田 康 行* 田 島 卓 也* 山 口 奈 美* 崎 瀆 智 美*
山 口 志保子* 帖 佐 悦 男*

\section{Study of the Approach to Treatment of Combined Ligament Injury Involving Posterior Cruciate Ligament of the Knee}

\author{
Yu Fukao*, Keitaro Yamamoto*, Hiroaki Yano*, Katsuhiro Kawahara*, \\ Yasuyuki Ishida*, Takuya Tajima*, Nami Yamaguchi* ${ }^{*}$ Tomomi Sakihama*, \\ Shihoko Yamaguchi*, and Etsuo Chosa*
}

膝複合勒帯損傷は交通外傷, 転落事故やハイエナジースポーッによって生じ, 損傷䨣帯の組み合わせや 各々の再建方法など治療方針の決定にしばしば難渋することがある。 PCL 単独損傷例ではしばしば保存 的に経過を観察されるが，PCL を含む膝複合勒带損傷例では近年他の勒帯之同様に手術的に加療される 傾向にある。平成 17 年 6 月より平成 20 年 7 月の間に PCL を含む膝複合靯帯再建術を施行した 5 例 5 膝 に対し, 文献的考察を加え報告する。受傷原因は柔道 2 例, スキー, 交通事故, 転落が各 1 例で, すべて 男性であった。平均年齢は 29.0 歳（17〜 42 歳）であった。損傷勒帯の内訳は ACL + PCL + MCL が 2 例, ACL + PCL, MCL + PCL，LCL + PCL が各 1 例であった。これらの症例に対し，損傷勒帯を同時再建も しくは修復術を行った．PCLの再建材料は全例自家ハムストリング腱を用いた。適応・再建法および術 後成績について検討する.

The combined ligament injury of the knee is caused by traffic accidents and high-energy-sports etc., and often the choice of treatment for combined ligament injuries involving the posterior cruciate ligament of the knee is difficult. Posterior cruciate ligament injury is usually treated by conservative management, but recently combined ligament injuries involving the posterior cruciate ligament are treated by the surgery as that for other ligament injuries of the knee. Five knees treated by combined ligament reconstruction involving the posterior cruciate ligament between June 2005 and July 2008 are reported with bibliographical consideration.

Two cases were injured by judo, and the other three cases were injured by skiing, traffic accident and falling respectively. All cases are male. Their mean ago was 29.0 years old (range: 17 to 42 ). Two cases injured PCL+ACL+MCL, and the other three cases injured PCL+ACL, PCL+MCL and PCL+ LCL. These cases were treated by combined ligament reconstruction and repair. PCL was reconstructed with autogenic hamstring in all cases. The indication, method of reconstructions and postoperative results are discussed.

Key words : knee joint (膝関節), combined ligament injury (複合靱帯損傷), posterior cruciate ligament (後十字勒帯), ligament reconstruction（勒帯再建術）

は じめに

膝複合靯帯損傷は交通外傷, 転落事故やハイエナジー スポーツによって生じ, 四肢の外傷の中でも最も治療
が困難な外傷の一つで，治療法は損傷靯帯の組み合わ せと，新鮮例か陳旧例かによって大きく異なる，PCL 単独損傷例ではしばしば保存的に経過を観察されるが, PCL を含む膝複合靭帯損傷例では他の靱帯と同様に

\footnotetext{
* 宮崎大学医学部整形外科学教室 Department of Orthopedic Surgery, Faculty of Medicine, University of Miyazaki, Miyazaki, Japan
} 
表 1 症例

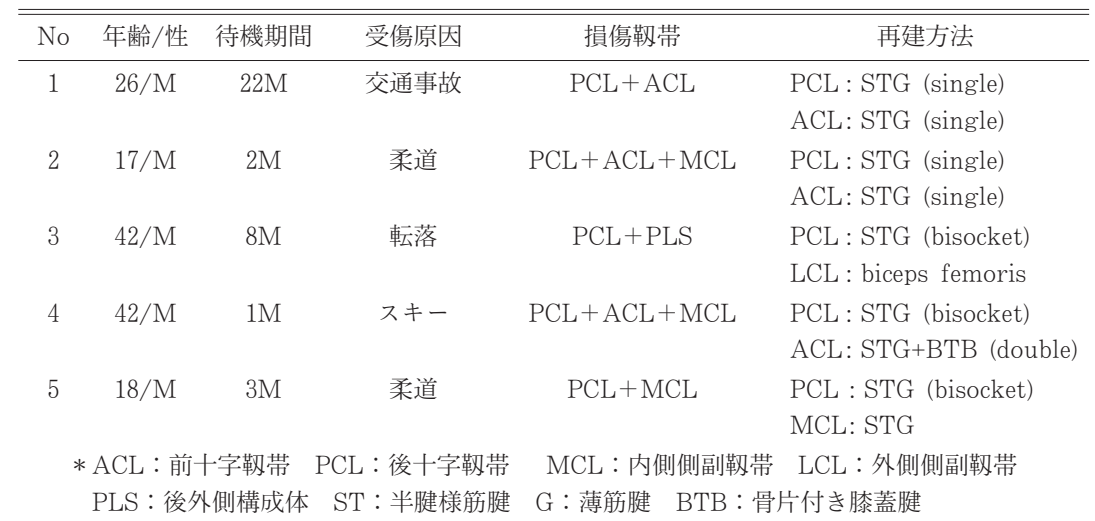

表 2 術後臨床成績

\begin{tabular}{|c|c|c|c|c|c|c|c|c|c|c|}
\hline \multirow[b]{2}{*}{ No } & \multirow{2}{*}{$\begin{array}{l}\text { 評価時期 } \\
\text { 術後ヶ月 }\end{array}$} & \multicolumn{3}{|c|}{ Lysholm knee score } & \multicolumn{3}{|c|}{ Sagging } & \multicolumn{3}{|c|}{ PDS } \\
\hline & & 術前 & & 術後 & 術前 & & 術後 & 術前 & & 術後 \\
\hline 1 & 36 & 68 & $\Rightarrow$ & 88 & ++ & $\Rightarrow$ & +- & + & $\Rightarrow$ & +- \\
\hline 2 & 39 & 評価不能 & $\Rightarrow$ & 103 & + & $\Rightarrow$ & +- & + & $\Rightarrow$ & - \\
\hline 3 & 15 & 24 & $\Rightarrow$ & 71 & + & $\Rightarrow$ & - & + & $\Rightarrow$ & - \\
\hline 4 & 12 & 37 & $\Rightarrow$ & 101 & + & $\Rightarrow$ & - & + & $\Rightarrow$ & - \\
\hline 5 & 7 & 46 & $\Rightarrow$ & 91 & + & $\Rightarrow$ & - & + & $\Rightarrow$ & - \\
\hline
\end{tabular}

手術的に加療される傾向にある. 今回, 我々は平成 17 年 6 月より平成 20 年 7 月までの期間に後十字靶帯 （以下 PCL）を含む膝複合鞀帯再建術を施行した 5 例 5 膝を経験したため, 文献的考察を加え報告する.

\section{対象亡方法}

対象は平成 17 年 6 月より平成 20 年 7 月までの期間 に PCL を含む膝複合鞀帯再建術を施行した 5 例 5 膝 で, 手術時平均年齢は 29.0 歳 (17〜 42 歳), 術前待 機期間は平均 7.2 ヶ月（ $1 \sim 22$ ヶ月）, 術後観察期間 は平均 22.3 ヶ月（ 7 〜 39 ヶ月）であった．受傷原因 は交通事故 1 例, 転落 1 例, 柔道 2 例, スキー 1 例で あった。損傷靯帯は PCL+ACL+MCL が 2 例, PCL+ACL が 1 例, PCL+MCL が 1 例, PCL + PLS が 1 例であり，再建方法は PCL に対しいずれも自家 ハムストリング腱を用い，2 例は single-socket で，3 例は bi-socketで再建した。症例 2 では当科初診時 MCL 嵌頓認めていたため，急性期に MCL 修復術を 施行し, 可動域回復を待ってから PCL + ACL 同時再 建術へ踏み切り, 二期的手術を行っているが, その他
4 膝では受傷後可動域回復を待ち, 一期的に複合勒帯 同時再建術を行っている（表 1 ）.

これらの症例に対して評価方法には，機能評価・主 観的評価として Lysholm score を用い，後方不安定 性の評価は sagging 徵候および Posterior drawer $\operatorname{sign}$ (以下 PDS）の有無を調査した。

\section{結果}

術中，術後を通して合併症はなかった。術後最終観 察時にはすべての症例が術前の生活レベルおよびスポー ッレベルに復帰していた。術後可動域における伸展制 限は全例で認められず，屈曲制限む全例で認めず，正 座が可能であった。術後 PDS は 1 膝で $( \pm), 4$ 膝で （一）であった。術後 Sagging は 2 膝で（士），3 膝 で（一）であった。うち 1 膝は PDS・Sagging とも に（土）であった。 術後 Lysholm score は平均 90.8 点で, 1 膝で fair, 2 膝で good, 2 膝で excellent で あった。術後PDS または Sagging で（土）であった 2 膝は, PCL を再建材料に STG 用いて singlesocket で再建していた。他 3 膝はSTGを用いて bi- 


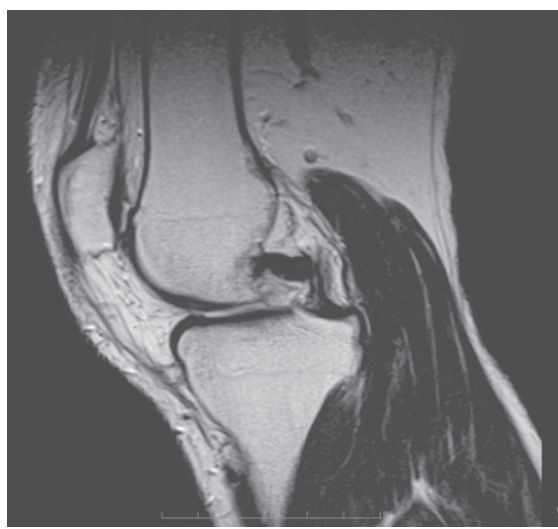

a ) 矢状断像

PCL に緊張感がなく high intensity area を認 める

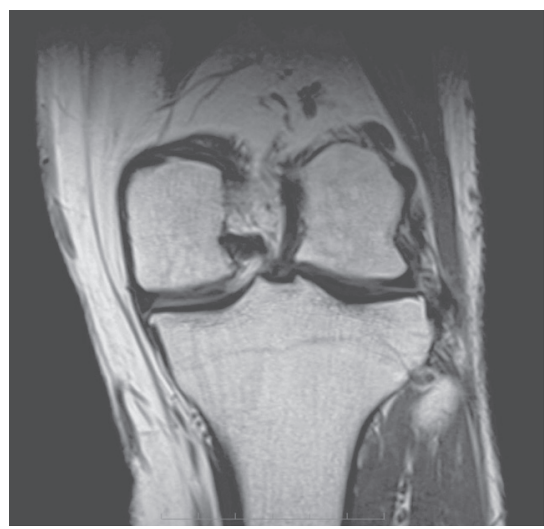

b )冠状断像

LCL 周囲に関節内水腫と思われる high intensity area を認める

図 1 術前 MRI 画像：左膝 $\mathrm{T} 2$ 強調画像

socket で再建している（表 2 ).

症例

42 歳男性. 職業販売業. 穴を掘っていたところ誤っ て $30 \mathrm{~cm}$ 程の深さの穴へ転落し受傷. 近医受診し, PCL 損傷指摘され保存加療にて経過観察されていた が膝崩れの症状は軽快せず，手術目的で当科外来受診 された。

初診時理学所見：膝蓋跳動 $(-)$, 腫脹・熱感 $(-)$, 可動域は深屈曲・完全伸展は可能であった. Sagging $(+), \operatorname{PDS}(+)$ であった. Dial test は $90^{\circ} / 30^{\circ}$ と あに（+), McMurray testは外旋で $(+)$ であった。 Lysholm score は2 4 点であった.

画像所見：X 線撮影では内側関節裂隙の狭小化の 初期变形性関節症所見認めた。左膝関節 MRI では, PCL 断裂認め，また内側半月中節から後節にかけて Mink 分類 Grade II の損傷，外側半月の前節に Mink 分類 Grade III の水平断裂, 外側側副靱帯に T2 強調画 像で high intensity 認め，関節内水腫が疑われた (困 1 ).

治療：受傷後 8 ヶ月で左膝 PCL + LCL 同時再建術 およびMM 切除術施行した，PCL に対しては，患側 ST および患側 G を用いて bi-socketで再建した。 LCL については患側有茎 biceps を用いて大腿骨外側 顆に post screw で固定した。内側半月については後 節に L 型 flap 認めたため部分切除行った. タナは榊 原分類 Type A，外側半月および前十字勒帯について
は異常所見認めなかった（図 2 ).

術後臨床経過：術後 2 週までは軽度屈曲位固定とし， 術後 2 週より他動的可動域訓練を開始した．徐々に可 動域を上げ，完全伸展は術後 5 週，深屈曲は術後 5 6 ヶ月を目標とした。荷重については術後 3 週まで完 全免荷とし，3 週より部分荷重開始，5週で全荷重と した (図 2 ).

術後 1 年での理学所見では, 膝蓋跳動 $(-)$, 腫脹・ 熱感 (一), 可動域は深屈曲・完全伸展は可能であっ た. Sagging $(-), \operatorname{PDS}(-)$ であった. Dial test は $90^{\circ} / 30^{\circ}$ ともに（一）であった。患肢の明らかな 筋萎縮は患健側差 $3.4 \mathrm{~cm}$ 残存していた。 Lysholm score は 71 点で改善を認めた。術後 1 年 4 力月の時 点で経過良好とし，抜釘術および second look 施行し た. second look では, PCL 再建靶帯は緊張性良好で, その他明らかな異常所見は認めなかった．全荷重歩行 可能となり，現在術前の生活レベルまで回復されてい る.

考察

PCL を含む複合靱帯損傷の治療法は，意見が分か れており，いまだ Golden Standard と呼べるものは ない。濱田ら ${ }^{2)}$ は PCL を含む新鮮複合鞀帯損傷の治 療に対して, PLS 損傷合併例では可及的早期に PCL 再建と後外側構成体修復を行い， ACL 損傷合併例で は可動域回復を待ってから PCL + ACL 再建術を行う, MCL 損傷合併例では保存的に MCL の治療を行い可 


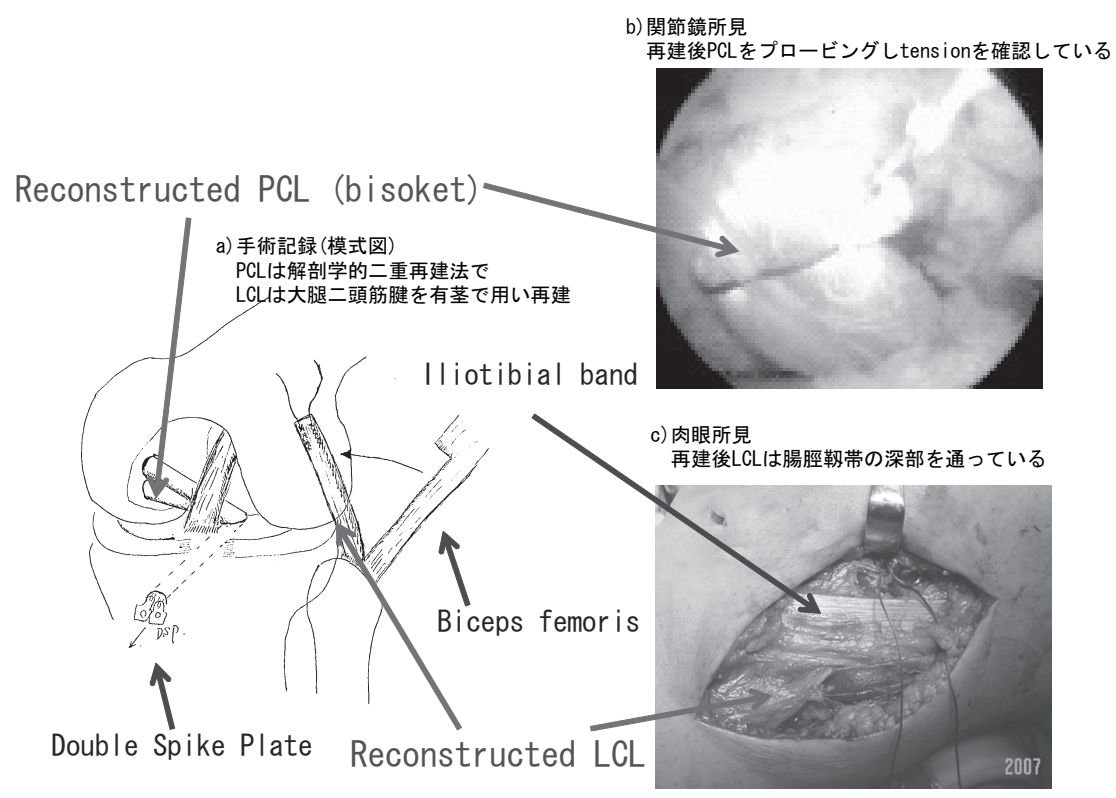

図 2 術中所見

動域回復を待ってから PCL の治療方針を決定すると している。今回，我々は PCL を含む新鮮複合靭帯損 傷例 5 例 5 膝に対して全例複合靶帯同時再建術を施行 した。

ここで当科での PCL を含む複合靱帯損傷例の治療 方針について述べる。ACL 合併損傷例では全後方動 摇性を認める場合には PCL + ACL 再建術を，後方動 摇性のみでも陳旧例で自覚症状認める場合には PCL 単独再建術を行う。 MCL 合併損傷例では，よ゙ちらむ 単独損傷の場合には基本的には保存加療を行う勒帯で あるが，複合靶帯損傷の場合，新鮮例で MCL 修復を 要するもので明らかな後方動摇性を認める症例には積 極的に PCL 再建術を同時に行う。また陳旧例で自覚 症状を伴うものには PCL+MCL 同時再建術を行う. PLS 損傷合併例では，重度の内反および外反動摇性 および後方動摇性が予想されるため積極的に観血的治 療を行う方針としている．新鮮例で後方動摇性が存在 するものに対しては PLS 修復術に加え PCL 再建術を 同時に行う。陳旧例でも自覚症状を伴うものには PCL + PLS 同時再建術を行う．本症例でも陳旧性の 複合䩚帯損傷（PCL+LCL 損傷）で後方動摇性の自 覚症状が残存していたため，当科の治療方針に基づき PCL + LCL 同時再建術を施行し，良好な結果を得る
ことが出来た。

また複合靱带損傷に対して同時再建術を施行する場 合，再建材料む意見の分かれるところである。特に PCL については，その損傷頻度が少ないこと，また 基礎的研究が盛んでないことから，治療法については いまだ不明の点が多い，移植腱の選択についても同様 で BTB は力学的強度に優れ，早期に骨癒合による生 物学的固着が得られる自家腱である一方，術後腱採取 部の痛みが問題となる。また自家ハムストリング腱は 鏡視下再建を行う際にその扱いが容易であり, bisocket 法への応用が可能であり，これは生体工学的 にも有利であるため当科ではこれを選択している.

ここで合併損傷䩲帯別での当科の再建材料の選択方 針を示す．PCL+ACL 合併損傷の場合， PCL は患側 のSTG を用いて bi-socket で，ACL は健側の STG を用いて double bundle で再建している。これも PCL と同様, STG む用いて解剖学的二重再建を行う ことで生体工学的にも有利となり，BTBでは術後腱 採取部の疼痛が問題となるため STGを選択してい $3^{4)}$.また PCL+MCL 合併損傷の場合， PCL は健側 の STGを用いて，MCL は患側のハムストリング腱 を用いて有茥で再建する，MCL の再建材料は，腸脛 靭帯（以下 ITB）では Hamstring を十字靭帯再建に 
温存出来るというメリットがあるが，別皮切を用いる ことで創の拡大による術後疼痛の残存やコスメティッ クな問題，また筋へルニアの生じる可能性が高まるた め, また遊離ハムストリング腱では有茥と比べ解剖学 的な位置に再建できるという利点があるが，有茎では Tendon-Bone-Junction を温存出来るため, 当科では 再建材料に有茥ハムストリング腱を用いている．最後 に PCL+PLS 合併損傷の場合であるが, PCL は健側 の STG を用いて，LCL には患側有茥大腿二頭筋腱を 用いている。これも Tendon-Bone-Junction を温存 出来るため, 八ムストリング腱ではなく, 当科ではこ ちらを選択している。 今回の 5 例 5 膝でもこの方針に 基づき再建材料を選択し再建している。 また症例 1 と 2 では PCL を single-socket で再建していたが，より 解剖学的な再建法である bi-socket 法で良好な成績を 得ているため, 当科では現在 bi-socket 法で再建して いる.しかし当科の症例数は少なく, PCLの再建法 についてはいまだ Golden Standard と呼べるものは ない，今後む長期成績を含め経過観察を行い，検討の 必要があると考える。

\section{結語}

1. PCL 損傷を合併した複合靱帯損傷に対し，PCL
との同時再建術を施行した 5 例を経験した。

2 . 当科では可能な限り同時再建術を行っており，良 好な成績を得ることが出来た。

3.再建材料については，いまだ確立された治療法は なく，長期成績を含め今後検討していく必要がある.

\section{参 考 文 献}

1）冨士川恭輔ほか：膝複合靱帯損傷の病態。骨・関節 ・ 靭帯, 10(7) : 807-816, 1997.

2）濱田雅之ほか：後十字靭帯損傷の診断之治療方針. MB Orthop., 15(4) : 39-46, 2002.

3）一戸貞文：膝複合靭帯損傷の治療法之問題点. MB Orthop., 15(4): 111-118, 2002.

4）石橋恭之ほか：解剖学的 2 重束後十字勒带再建術．関 節外科, 24(11)：1354-1359, 2005.

5）三岡智規ほか：新鮮前・後十字勒帯複合損傷に対する 一時的手術治療とその問題点. MB Orthop., 14(1) : 4348, 2001.

6）宮田康史ほか：陳旧性重度複合靯带損傷に対する前㧍 よび後十字靭帯同時再建術の臨床成績. 骨・関節・勒帯, 10(7) : 863-868, 1997.

7）白倉賢二ほか：新鮮前・後十字勒帯複合損傷に対する 保存的治療とその限界. MB Orthop., 14(1)：37-41, 2001.

8）安田和則ほか：前および後十字勒帯複合勒帯損傷に対 する靱帯再建術の成績. 臨整外，36(6)：731-739， 2001. 